\title{
SINTESIS FOAMING AGENT ASAM LAURAT SAWIT DAN KARAKTERISTIK SIFAT FISIKOKIMIA
}

\section{SYNTHESIS OF FOAMING AGENT PALM LAURIC ACID AND CHARACTERISTICS OF PHYSICOCHEMICAL PROPERTIES}

\author{
Jihan Pradesi ${ }^{1{ }^{*}}$, Erliza Hambali ${ }^{2)}$, dan Endang Warsiki ${ }^{2)}$ \\ ${ }^{1)}$ Program Studi Teknologi Industri Pertanian, Fakultas Teknologi Pertanian, Institut Pertanian Bogor \\ Kampus IPB Darmaga, Bogor 16680, Jawa Barat, Indonesia \\ E-mail: jihanpradesi@gmail.com; jihan.pradesi@yahoo.com \\ ${ }^{2)}$ Departemen Teknologi Industri Pertanian, Fakultas Teknologi Pertanian, Institut Pertanian Bogor
}

Makalah: Diterima 28 Mei 2017; Diperbaiki 9 November 2017; Disetujui 20 Desember 2017

\begin{abstract}
Synthesis of foaming agent was conducted by reacting fatty acid of vegetable oil and alkaline. In this study, the selected fatty acid consisted of palm oil as raw material; with $\mathrm{NaOH}$ and $\mathrm{KOH}$ as alkali materials. The factor observed was molar ratio of reactant added into reactor. This research was aimed to determine the best molar ratio to produce foaming agent from lauric acid, to know its physico-chemical propertie,; and to obtain the foaming agent performance. Statistical analysis result indicated that the alkali type and molar ratio exhibited significant influence on $\mathrm{pH}$, viscosity, density, surface tension, contact angle, interfacial tension, foamstability, and emulsion stability. The best ratio was by $1 \mathrm{~mol}$ of lauric acid and $0.5 \mathrm{~mol}$ of $\mathrm{KOH} 30 \% \mathrm{w} / \mathrm{w}$ with characteristics as followed test was performed at room temperature for $24 \mathrm{~h}, \mathrm{pH}$ of 9.88, density of 0.9959 $\mathrm{g} / \mathrm{cm}^{3}$, viscosity of $1.85 \mathrm{cP}$, surface tension of 3.14 dyne/cm, interfacial tension of 8.39 dyne/cm, and contact angle of $18.28^{\circ}$ in the $10^{\text {th }}$ minute (with initial angle of $73.99^{\circ}$ ). Foam and emulsion stability test were carried out and indicated that Na-laurate foaming agent showed higher performance than K-laurate.
\end{abstract}

Keywords: alkali, foaming agent, lauric acid, palm oil

\section{ABSTRAK}

Sintesis foaming agent dilakukan dengan mereaksikan asam lemak dari minyak nabati dan alkali. Pada penelitian ini asam lemak yang dipilih adalah minyak sawit dan alkalinya $\mathrm{NaOH}$ dan $\mathrm{KOH}$. Faktor yang di inrestagasi adalah rasio molar asam laurat dan reaktan yang ditambahkan ke dalam reaktor. Penelitian ini bertujuan untuk mendapatkan rasio molar terbaik dari asam laurat dan alkali pada proses sintesis foaming agent; mendapatkan informasi sifat fisiko-kimia foaming agent yang dihasilkan; serta mengetahui kinerja foaming agent yang dihasilkan. Berdasarkan hasil analisis statistika menunjukkan bahwa jenis alkali dan rasio molar berpengaruh sangat nyata terhadap $\mathrm{pH}$, viskositas, densitas, tegangan permukaan, tegangan antarmuka, sudut kontak, stabilitas busa dan stabilitas emulsi yang dihasilkan. Foaming agent terbaik dihasilkan pada rasio molar 1:0,5 asam laurat dan alkali $\mathrm{KOH} 30 \%$, dengan analisis sebagai berikut : pengujian stabilitas busa pada suhu ruang bertahan selama $24 \mathrm{jam}, \mathrm{pH} 9,88$, densitas $0,9959 \mathrm{~g} / \mathrm{mL}$, viskositas 1,85 $\mathrm{cP}$, tegangan permukaan 3,14 dyne/cm, tegangan antarmuka 8,39 dyne/cm dan sudut kontak $18,28^{\circ}$ di menit ke 10 (dari $73,99^{\circ}$ di menit ke 0 ). Berdasarkan hasil stabilitas busa dan stabilitas emulsi, kinerja foaming agent Na-laurat memiliki kinerja lebih baik dari K-laurat.

Kata kunci: alkali, foaming agent, asam laurat, minyak sawit

\section{PENDAHULUAN}

Foaming agent adalah bahan pembentuk busa yang mampu menurunkan tegangan permukaan dan tegangan antarmuka antara campuran dua material atau lebih. Foaming agent bersifat hampir sama seperti surfaktan yang dapat menurunkan tegangan permukaan suatu cairan dan meningkatkan kestabilan pembentukan busa. Busa (foam) adalah suatu dispersi yang terdiri atas gelembung gas yang dibungkus oleh lapisan cairan. Bahan baku foaming agent sebagian besar masih diimpor, umumnya terbuat dari bahan-bahan minyak bumi yang ketersediaannya terbatas dan sulit untuk terdegradasi di alam (Krol et al., 2012). Salah satu bahan dasar untuk membuat foaming agent adalah minyak sawit dan turunannya yang bersifat ramah lingkungan dan memiliki toksisitas rendah.

Industri pengolahan kelapa sawit di Indonesia merupakan industri yang sangat strategis karena Indonesia merupakan penghasil kelapa sawit terbesar dunia. Pada tahun 2016 produksi CPO Indonesia 31,3 juta ton (Ditjenbun, 2016). Upaya pemanfaatan sumber daya alam dan bahan pertanian seperti minyak sawit dalam menghasilkan beragam produk turunan perlu dilakukan. Hal ini sangat sesuai dengan semangat ramah lingkungan yang telah berkembang di berbagai negara saat ini. 
Indonesia mampu memproduksi minyak sawit yang melimpah namun jenis dan variasi produk turunan yang dihasilkan masih lebih rendah dibandingkan dengan Malaysia. Pemanfaatan minyak sawit sebagai foaming agent diharapkan dapat mengurangi ketergantungan terhadap produk impor dan mendukung berkembangnya diversifikasi produk olahan minyak sawit.

Penelitian ini menggunakan bahan baku asam laurat yang merupakan bentuk gliserida dari minyak sawit untuk memproduksi foaming agent. Asam laurat merupakan asam lemak jenuh dengan rantai hidrokarbon berjumlah 12 (Simeh, 2004). Hasil sintesis foaming agent menggunakan asam laurat dapat larut dengan busa dalam air, sifat detergensinya yang baik dan kinerja yang baik pada air sadah. Asam laurat memiliki sifat pembusaan yang lebih baik dibanding dengan asam lainnya (Belitz dan Grosch, 2004). Melalui proses saponifikasi akan dihasilkan sabun jenis sodium laurat dan potasium laurat. Rasio molar yang digunakan dalam proses saponifikasi antara asam laurat dan basa $\mathrm{Na} / \mathrm{KOH}$ adalah 1:0,5, 1:0,75, dan 1:1 yang akan menghasilkan 1 molar sabun. Pada penelitian Kozeta et al. (2011), reaksi saponifikasi minyak biji bunga matahari dilakukan pada suhu 90 $95^{\circ} \mathrm{C}$ selama 2 jam dengan rendemen sabun murni yang dihasilkan adalah 98,37\% (w/w). Penelitian ini bertujuan untuk (1) mendapatkan rasio molar dan jenis alkali terbaik pada proses sintesis foaming agent, (2) mendapatkan informasi sifat fisiko-kimia foaming agent yang dihasilkan, serta (3)mengetahui kinerja foaming agent yang dihasilkan.

\section{BAHAN DAN METODE}

\section{Bahan dan Alat}

Bahan yang digunakan pada penelitian ini adalah asam laurat dengan kemurnian $100 \%$ yang didapat dari PT. SOCI MAS Medan, $\mathrm{NaOH}$ teknis yang dibuat konsentrasi $30 \%, \mathrm{KOH}$ teknis yang dibuat konsentrasi $30 \%$, akuades, dan bahan kimia lain untuk keperluan analisis. Peralatan yang digunakan dalam penelitian ini adalah density meter anton Paar DMA $4500 \mathrm{M}$, spinning drop tensiometer, viscometer brookfield DV-III Ultra, motor pengaduk, mixing, pH meter Schott, neraca analitik Precisa XT220A, homogenizer, gelas kimia, serta alat-alat untuk analisa lainnya.

\section{Tahapan Penelitian}

\section{Analisis Karakteristik Fisikokimia Asam Laurat}

Analisis yang dilakukan terhadap asam laurat adalah bilangan asam SNI 01-3555-1988, bilangan penyabunan SNI 01-3555-1998, bilangan iod SNI 01-3555-1998, titik leleh (material safety data sheet (MSDS) ), titik didih (material safety data sheet (MSDS) ), viskositas (viscometer Brookfield DV-III ultra), dan densitas (densitymeter DMA 4500M Anton Paar).

\section{Sintesis Pembuatan Foaming Agent}

Proses sintesis foaming agent dalam penelitian ini dilakukan melalui proses saponifikasi pada umpan $\mathrm{C}_{12} \mathrm{H}_{24} \mathrm{O}_{2}+\mathrm{KOH} \rightarrow \mathrm{C}_{12} \mathrm{H}_{23} \mathrm{KO}_{2}+\mathrm{H}_{2} \mathrm{O}$. Proses pembuatan foaming agent dengan melelehkan asam laurat pada suhu $65^{\circ} \mathrm{C}$ kemudian ditambahkan alkali ( $\mathrm{NaOH}$ konsentrasi $30 \%$ dan $\mathrm{KOH}$ konsentrasi $30 \%$ ) dengan kecepatan pengadukan 8-15 rpm tekanan $1 \mathrm{~atm}$ selama 90 menit. Adapun diagram alir pembuatan foaming agent yang dilakukan dapat dilihat pada Gambar 1

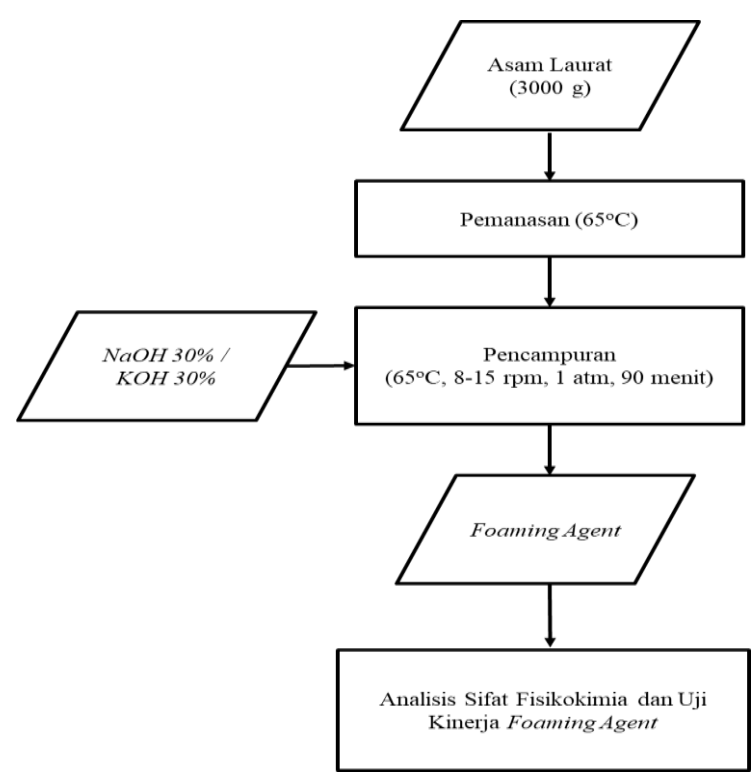

Gambar 1. Diagram alir penelitian

\section{Rancangan Penelitian}

Penelitian sintesis foaming agent menggunakan model rancangan acak lengkap (RAL) dengan 2 faktor yaitu jenis alkali dengan dua taraf yaitu $\mathrm{NaOH} 30 \%$ dan $\mathrm{KOH} 30 \%$, dan rasio molar (asam laurat dan alkali) dengan tiga taraf yaitu 1:0,5, 1:0,75, 1:1 dan dua kali ulangan. Model matematika dalam penelitian ini sebagai berikut:

$$
\mathrm{Y}_{\mathrm{ijk}}=\mu+\mathrm{A}_{\mathrm{i}}+\mathrm{B}_{\mathrm{j}}+(\mathrm{AB})_{\mathrm{ij}}+\varepsilon_{\mathrm{ijk}}
$$

Keterangan:

$$
\begin{aligned}
\mathrm{Y}_{\mathrm{ijk}}= & \text { hasil pengamatan } \\
\mu & =\text { nilai rata-rata umum } \\
\mathrm{A}_{\mathrm{i}}= & \text { pengaruh jenis alkali (A) taraf ke-i } \\
& \text { (NaOH 30\% dan KOH 30\% } \\
\mathrm{B}_{\mathrm{j}}= & \begin{array}{l}
\text { pengaruh rasio molar (asam laurat dan } \\
\text { alkali) }(\mathrm{B}) \text { taraf ke-j }(1: 0,5,1: 0,75, \text { dan }
\end{array} \\
& \begin{array}{l}
1: 1) \\
\text { pengaruh interaksi jenis alkali(A) taraf } \\
\text { ke-i dan rasio molar (B) taraf ke-j }
\end{array} \\
\mathrm{AB}_{\mathrm{ij}}= & \text { galat percobaan }
\end{aligned}
$$

\section{Analisis Sifat Fisikokimia Foaming Agent}

Analisis yang dilakukan adalah uji $\mathrm{pH}$ dengan $\mathrm{pH}$ meter, densitas menggunakan alat densitymeter DMA 4500M Anton Paar, viskositas 
menggunakan alat viscometer Brookfield DV-III ultra, tegangan antarmuka dengan spinning drop tensiometer, tegangan permukaan dengan spinning drop tensiometer, sudut kontak dengan contact angel Pheonix 300.

\section{Uji Kinerja Foaming Agent}

Uji kinerja pada foaming agent dilakukan terhadap stabilitas busa (Piyali et al., 1999) dan stabilitas emulsi (Piyali et al., 1999). Proses pengamatan dilakukan pada suhu ruang selama 3 hari.

\section{HASIL DAN PEMBAHASAN}

\section{Sifat Fisikokimia Asam Laurat}

Penelitian sintesis foaming agent ini menggunakan bahan baku asam laurat. Asam laurat merupakan salah satu hasil fraksinasi berbentuk padat dari asam lemak minyak sawit. Sebelum dilakukan proses saponifikasi, maka analisis asam laurat diperlukan untuk mengetahui sifat fisikokimia asam laurat. Adapun sifat fisikokimia yang diuji meliputi beberapa parameter yaitu bilangan asam, bilangan penyabunan, bilangan iod, titik leleh, titik didih, viskositas dan densitas. Hasil analisis asam laurat minyak sawit selengkapnya disajikan dalam Tabel 1.

Tabel 1. Hasil analisis asam laurat minyak sawit

\begin{tabular}{llr} 
Parameter & Satuan & Hasil Analisis \\
\hline Bilangan Asam & $\mathrm{mg} \mathrm{KOH} / \mathrm{g}$ & 280,6 \\
Bilangan & $\mathrm{mg} \mathrm{KOH} / \mathrm{g}$ & 281,6 \\
Penyabunan & $\mathrm{g} / 100 \mathrm{~g}$ & 0,1 \\
Bilangan Iod & ${ }^{\circ} \mathrm{C}$ & 43 \\
Titik Leleh & 197 \\
Titik Didih & ${ }^{\circ} \mathrm{C}$ & 4,26 \\
Viskositas & $\mathrm{cP}$ & 0,86650 \\
$\left(70^{\circ} \mathrm{C}\right)$ & $\mathrm{g} / \mathrm{cm}^{3}$ & \\
Densitas $\left(70^{\circ} \mathrm{C}\right)$ &
\end{tabular}

\section{Sifat Fisiko Kimia Foaming Agent}

Analisis sifat fisikokimia foaming agent diperlukan karena akan menentukan kualitas busa yang dihasilkan. Adapun sifat fisikokimia foaming agent yang diuji meliputi nilai $\mathrm{pH}$, densitas, viskositas, tegangan permukaan, tegangan antarmuka, dan sudut kontak.

\section{Nilai pH}

Hasil analisis sidik ragam $(\alpha=0,05)$ menunjukkan bahwa jenis alkali dan rasio molar tidak memberikan pengaruh yang nyata terhadap nilai $\mathrm{pH}$ foaming agent. Nilai $\mathrm{pH}$ foaming agent yang diperoleh dari hasil pengukuran berkisar 9,639,99 (Tabel 2). Pada Tabel 2 disajikan pengaruh jenis reaktan dan rasio molar asam lemak dengan jenis alkali terhadap nilai $\mathrm{pH}$ foaming agent.
Nilai $\mathrm{pH}$ juga berkaitan dengan konsentrasi ion hidrogen sebagai bagian komponen keasaman dan konsentrasi ion hidroksil sebagai bagian komponen kebasaan (Rondinini et al., 2001). Pada kondisi $\mathrm{pH}$ netral maka konsentrasi kedua ion tersebut seimbang namun jika konsentrasi ion hidrogen lebih besar dibanding ion hidroksil maka $\mathrm{pH}$ cenderung asam (rendah). $\mathrm{NaOH}$ dan $\mathrm{KOH}$ sebagai alkali pada proses foaming agent bersifat basa kuat, sehingga produk foaming agent yang dihasilkan bersifat basa.

Tabel 2. Pengaruh jenis alkali dan rasio molar (asam laurat : $\mathrm{NaOH}-\mathrm{KOH}$ ) terhadap $\mathrm{pH}$ foaming agent

\begin{tabular}{lccc}
\hline \multirow{2}{*}{$\begin{array}{c}\text { Jenis } \\
\text { alkali }\end{array}$} & \multicolumn{3}{c}{ Rasio Molar } \\
\cline { 2 - 4 } & $\mathbf{1 : 0 , 5}$ & $\mathbf{1 : 0 , 7 5}$ & $\mathbf{1 : 1}$ \\
\hline $\mathrm{NaOH}$ & $9,63 \pm 0,01$ & $9,74 \pm 0,01$ & $9,86 \pm 0,01$ \\
$\mathrm{KOH}$ & $9,88 \pm 0,01$ & $9,96 \pm 0,01$ & $9,99 \pm 0,01$ \\
\hline
\end{tabular}

\section{Densitas}

Densitas merupakan salah satu sifat dasar fluida yang didefinisikan massa per satuan volume. Efek temperatur pada densitas cairan tidak dapat diabaikan karena cairan akan meregang mengikuti perubahan suhu. Densitas umumnya dikaitkan dengan viskositas dimana cairan lebih padat maka viskositasnya lebih tinggi, hal ini tentunya berkorelasi dengan kandungan total padatan pada bahan. Nilai densitas foaming agent berkisar 0,9965$0,9962 \mathrm{~g} / \mathrm{cm}^{3}$. Data densitas foaming agent disajikan pada Gambar 2.

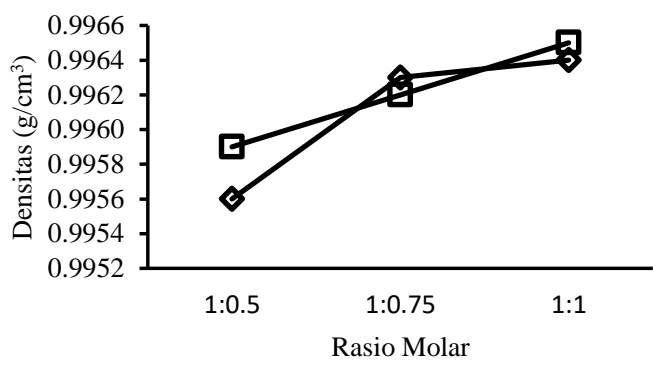

Gambar 2. Pengaruh jenis alkali dan rasio molar (asam laurat : $\mathrm{NaOH}-\mathrm{KOH}$ ) terhadap densitas foaming agent. $-\square-\mathrm{KOH},-\diamond-$ $\mathrm{NaOH}$

Analisis ragam untuk densitas menunjukan bahwa asam laurat dan jenis alkali tidak berpengaruh nyata, sedangkan interaksi antara faktor rasio molar dengan alkali memberikan pengaruh yang signifikan. Pada hasil uji lanjut Duncan, rasio molar tiap taraf memberikan hasil yang berbeda nyata. Adapun hasil uji lanjut Duncan terhadap rasio molar menunjukkan bahwa antara taraf 1:0,5 dan 1:0,75, 1:0,5 dan 1:1, serta 1:0,75 dan 1:1 saling berbeda nyata. Semakin banyak alkali yang ditambahkan akan meningkatkan nilai densitas. 


\section{Viskositas}

Hasil analisis sidik ragam $(\alpha=0,05)$ menunjukkan bahwa jenis alkali, rasio molar (asam laurat : $\mathrm{NaOH}-\mathrm{KOH}$ ) memberikan pengaruh berbeda nyata terhadap nilai viskositas foaming agent. Jenis alkali memberikan hasil berbeda nyata antara $\mathrm{NaOH}$ dan $\mathrm{KOH} 30 \%$ pada hasil uji Duncan, semakin banyak alkali yang ditambahkan akan menurunkan nilai viskositas. Nilai viskositas foaming agent kisaran 1,07 cP-1,85 cP. Hasil uji lanjut Duncan terhadap perbandingan rasio molar menunjukkan bahwa antara taraf 1: 0,5 dan 1:0,75, 1:0,5 dan 1:1, serta 1: 0,75 dan 1:1 saling berbeda nyata. Kenaikan viskositas menurut Holmberg (2002) disebabkan karena meningkatnya konsentrasi partikel.

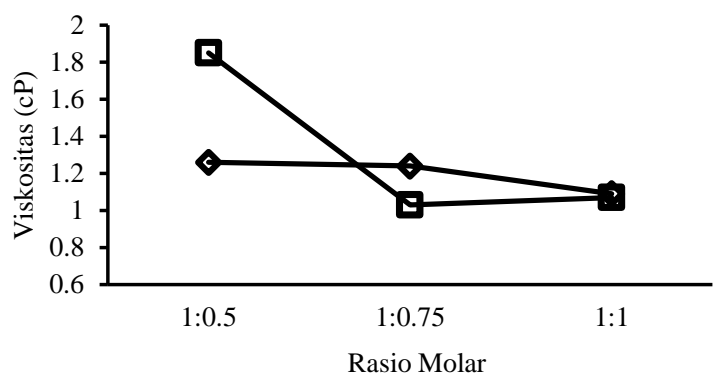

Gambar 3. Pengaruh jenis alkali dan rasio molar (asam laurat : $\mathrm{NaOH}-\mathrm{KOH}$ ) terhadap viskositas foaming agent. $-\square-\mathrm{KOH},-$ $\diamond-\mathrm{NaOH}$

\section{Tegangan Permukaan}

Hasil analisis sidik ragam $(\alpha=0,05)$ menunjukkan bahwa jenis alkali dan rasio molar (asam laurat : $\mathrm{NaOH}-\mathrm{KOH}$ ) memberikan pengaruh berbeda nyata terhadap nilai tegangan permukaan foaming agent. Uji lanjut Duncan untuk faktor rasio molar menunjukan bahwa antara taraf 1:0.5, 1:0,75, dan 1:1 masing-masing berbeda nyata. Nilai tegangan permukaan foaming agent berkisar antara 0,45 - 14,14 dyne/cm. Pada Gambar 4 disajikan pengaruh antara jenis alkali dan rasio molar terhadap nilai tegangan permukaan.

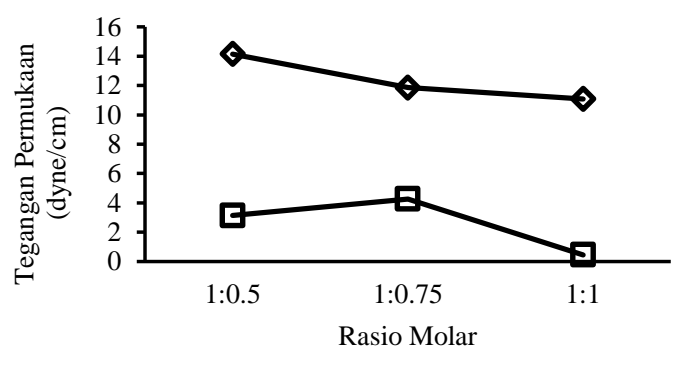

Gambar 4. Pengaruh jenis alkali dan rasio molar (asam laurat : $\mathrm{NaOH}-\mathrm{KOH}$ ) terhadap tegangan permukaan foaming agent. $-\square-$ $\mathrm{KOH},-\diamond-\mathrm{NaOH}$

\section{Tegangan Antarmuka}

Hasil analisis sidik ragam $(\alpha=0,05)$ menunjukkan bahwa jenis alkali dan rasio molar reaktan memberikan pengaruh berbeda nyata terhadap nilai tegangan antarmuka foaming agent. Uji lanjut Duncan untuk faktor rasio molar menunjukan bahwa antara taraf 1:0,5, 1:0,75, 1:1 masing-masing berbeda nyata. Nilai tegangan antarmuka foaming agent yang diperoleh dari hasil pengukuran berkisar antara 0,93-8,39 dyne/cm. Grafik pengaruh jenis alkali dan rasio molar terhadap nilai tegangan antarmuka dapat dilihat pada Gambar 5.

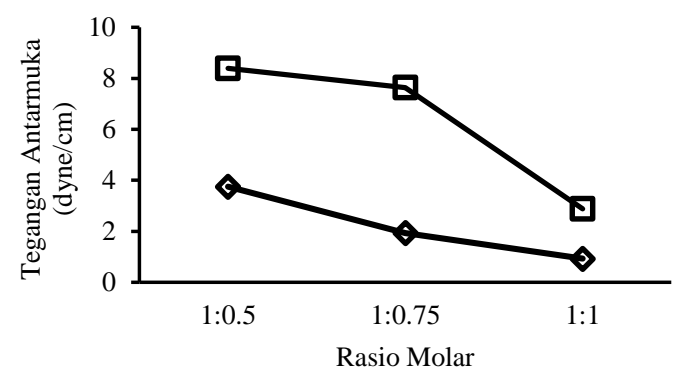

Gambar 5. Pengaruh jenis alkali dan rasio molar (asam laurat : $\mathrm{NaOH}-\mathrm{KOH}$ ) terhadap nilai tegangan antarmuka, $-\square-\mathrm{KOH}-$ $\diamond-\mathrm{NaOH}$

Terlihat pada Gambar 5 nilai tegangan antarmuka selalu lebih kecil daripada tegangan permukaan karena gaya adhesi antara dua cairan yang tidak bercampur akan lebih besar daripada gaya adhesi antara cairan dan udara. Nilai tegangan antarmuka terkecil pada rasio molar 1:1 menggunakan alkali $\mathrm{NaOH} 30 \%$ dengan nilai sebesar 0,93 dyne/cm, dan dengan perubahan $\mathrm{KOH}$ dengan nilai sebesar2,88 dyne $/ \mathrm{cm}$. Semakin tinggi perbandingan rasio molar pada foaming agent, kecenderungan nilai tegangan antarmuka semakin rendah. Untuk nilai tegangan antarmuka, ternyata alkali $\mathrm{NaOH}$ memberikan pengaruh nilai tegangan antarmuka yang lebih rendah dibandingkan menggunakan $\mathrm{KOH}$.

\section{Sudut Kontak}

Parameter wettability merupakan indikator yang menunjukkan interaksi molekuler antara cairan dan padatan melalui interaksi langsung pada daerah antarmuka. Daerah antarmuka dibentuk oleh dinding tabung dengan bidang singgung permukaan zat cair yang diakibatkan adanya gaya kohesi dan adhesi. Hasil analisis nilai sudut kontak larutan foaming agent menghasilkan kisaran nilai $12,48^{\circ}-73,99^{\circ}$. Grafik pengaruh jenis alkali dan rasio molar asam laurat dengan alkali terhadap sudut kontak foaming agent pada 0 dan 10 menit (Gambar 6).

Hasil pengujian sudut kontak foaming agent memperlihatkan bahwa rasio molar (asm laurat : $\mathrm{NaOH}-\mathrm{KOH})$ menghasilkan nilai sudut kontak yang 
berbeda. Nilai sudut kontak pada 0-10 menit memperlihatkan bahwa pada rasio molar (asam laurat : $\mathrm{NaOH}=1.0,75$ dan asam laurat $: \mathrm{KOH}=$ 1:0,5) diperoleh nilai $73,99^{\circ}$ dan $46,8^{\circ}$. Semakin kecil rasio molar maka nilai sudut kontaknya semakin besar. Sudut kontak foaming agentyang terbentuk dari asam laurat : $\mathrm{NaOH}$ lebih tinggi dibandingkan asam laurat : KOH. Hasil ini menunjukkan bahwa foaming agent efektif dalam mengubah wettability.

\section{Uji KinerjaFoaming Agent \\ Stabilitas Busa}

Stabilitas busa adalah kemampuan busa untuk mempertahankan parameter utamanya (ukuran gelembung, kandungan cairan, total volume busa) dalam keadaan konstan selama waktu tertentu. Analisis stabilitas busa dilakukan dengan tujuan mengetahui kemampuan busa untuk bertahan atau tidak hilang selama jangka waktu tertentu. Nilai stabilitas busa didapat dari selisih tinggi busa pada menit ke-0 setelah dihomogenkan dengan tinggi busa pada hari ke- 3 yang dinyatakan dalam satuan $\mathrm{cm}$ lalu dipersentasekan. Hasil pengujian nilai stabilitas busa memberikan kisaran 0-100\%. Pada Gambar 7 disajikan grafik pengaruh jenis alkali dan rasio molar asam lemak dengan jenis alkali $(\mathrm{NaOH}$ dan $\mathrm{KOH}$ ) terhadap stabilitas busa selama penyimpanan pada suhu ruang.

Pada hari pertama, busa Na-laurat berkisar $65 \%$ dan busa K-laurat berkisar $40 \%$. Pada pengujian hari kedua, terjadi penurunan hingga $70 \%$ untuk Na-laurat dan $25 \%$ pada K-laurat. Produk Nalaurat memiliki stabilitas busa yang lebih baik dibanding K-laurat.Hasil pengujian sudut kontak foaming agent memperlihatkan bahwa rasio molar (asm laurat : $\mathrm{NaOH}-\mathrm{KOH}$ ) menghasilkan nilai sudut kontak yang berbeda. Nilai sudut kontak pada 0-10 menit memperlihatkan bahwa pada rasio molar (asam laurat : $\mathrm{NaOH}=1.0,75$ dan asam laurat : $\mathrm{KOH}=1: 0,5)$ diperoleh nilai $73,99^{\circ}$ dan $46,8^{\circ}$. Semakin kecil rasio molar maka nilai sudut

0 menit

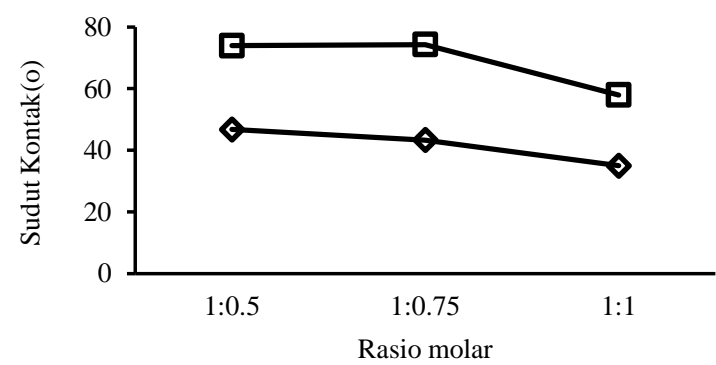

kontaknya semakin besar. Sudut kontak foaming agentyang terbentuk dari asam laurat : $\mathrm{NaOH}$ lebih tinggi dibandingkan asam laurat : $\mathrm{KOH}$. Hasil ini menunjukkan bahwa foaming agent efektif dalam mengubah wettability.

\section{Uji KinerjaFoaming Agent Stabilitas Busa}

Stabilitas busa adalah kemampuan busa untuk mempertahankan parameter utamanya (ukuran gelembung, kandungan cairan, total volume busa) dalam keadaan konstan selama waktu tertentu. Analisis stabilitas busa dilakukan dengan tujuan mengetahui kemampuan busa untuk bertahan atau tidak hilang selama jangka waktu tertentu. Nilai stabilitas busa didapat dari selisih tinggi busa pada menit ke-0 setelah dihomogenkan dengan tinggi busa pada hari ke- 3 yang dinyatakan dalam satuan cm lalu dipersentasekan. Hasil pengujian nilai stabilitas busa memberikan kisaran 0-100\%. Pada Gambar 7 disajikan grafik pengaruh jenis alkali dan rasio molar asam lemak dengan jenis alkali $(\mathrm{NaOH}$ dan $\mathrm{KOH}$ ) terhadap stabilitas busa selama penyimpanan pada suhu ruang.

Pada hari pertama, busa Na-laurat berkisar $65 \%$ dan busa K-laurat berkisar $40 \%$. Pada pengujian hari kedua, terjadi penurunan hingga $70 \%$ untuk Na-laurat dan $25 \%$ pada K-laurat. Produk Nalaurat memiliki stabilitas busa yang lebih baik dibanding K-laurat

\section{Stabilitas Emulsi}

Stabilitas emulsi foaming agent merupakan kekuatan sistem emulsi yang terdapat dalam foaming agent untuk mempertahankan stabilitasnya dalam berbagai kondisi. Stabilitas emulsi merupakan salah satu parameter penting dalam penentuan mutu sabun. Foaming agent yang dihasilkan berbentuk sabun padat. Sabun padat termasuk dalam emulsi tipe water in oil. Emulsi yang baik tidak membentuk lapisan-lapisan, tidak terjadi perubahan warna dan memiliki konsentrasi tetap (Suryani et al., 2002).

10 menit

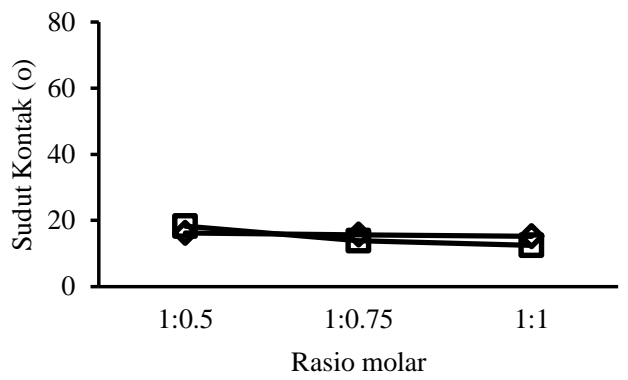

Gambar 6. Pengaruh jenis alkali dan rasio molar (asam laurat : NaOH-KOH) terhadap sudut kontak foaming agent pada 0 menit dan 10 menit.- $\mathrm{KOH},-\diamond-\mathrm{NaOH}$ 
Stabilitas emulsi akan mencapai maksimum apabila gaya tolak antara globula-globula fase kontinyu mencapai maksimum. Emulsi tidak stabil bila mengalami creaming, inversi, dan cracking/ koalesensi (demulsifikasi). Pengukuran stabilitas emulsi dilakukan dengan mencampurkan air, minyak dan foaming agent dengan perbandingan 8:1:1, dihomogenkan menggunakan homogenazer selama 15 menit dan dilakukan pengamatan jam ke 0, 6, 24, dan 48 untuk melihat perubahan ataupun pemisahan

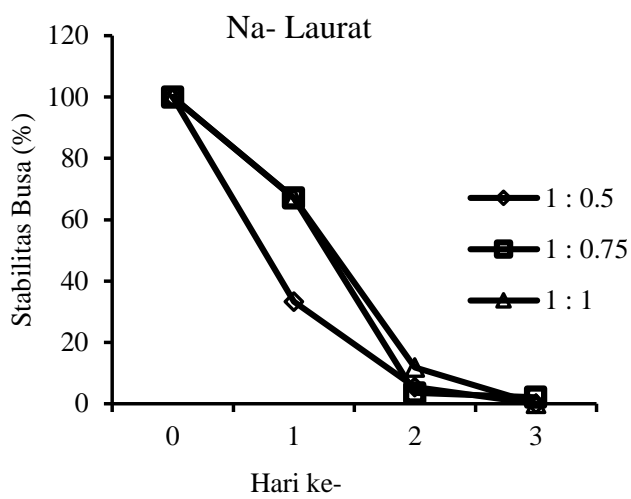

emulsi yang mungkin terjadi. Pada Gambar 8 disajikan grafik pengaruh jenis alkali dan rasio molar (asam laurat : $\mathrm{NaOH}-\mathrm{KOH}$ ) terhadap stabilitas emulsi selama penyimpanan pada suhu ruang.

Hasil pengukuran stabilitas emulsi menunjukkan kisaran nilai 12,4\% - 100\% hingga jam ke-48. Emulsi yang terbentuk sangat stabil, sedikit pemisahan emulsi terjadi pada beda alkali ( $\mathrm{NaOH}$ dan $\mathrm{KOH}$ ). Hal ini menunjukkan Na-Laurat dan K-Laurat memiliki sifat pengemulsi yang baik.

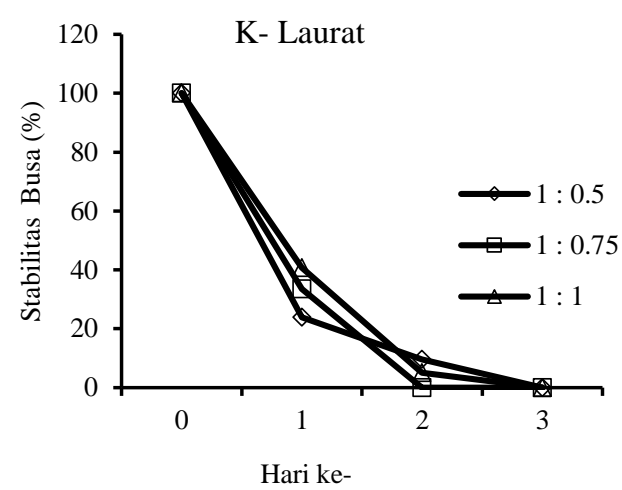

Gambar 7. Pengaruh jenis alkali dan rasio molar (asam laurat : $\mathrm{NaOH}-\mathrm{KOH}$ ) terhadap stabilitas busa selama penyimpanan pada suhu ruang. $-\checkmark-1: 0.5,-\square-1: 0.75,-\Delta-1: 1$
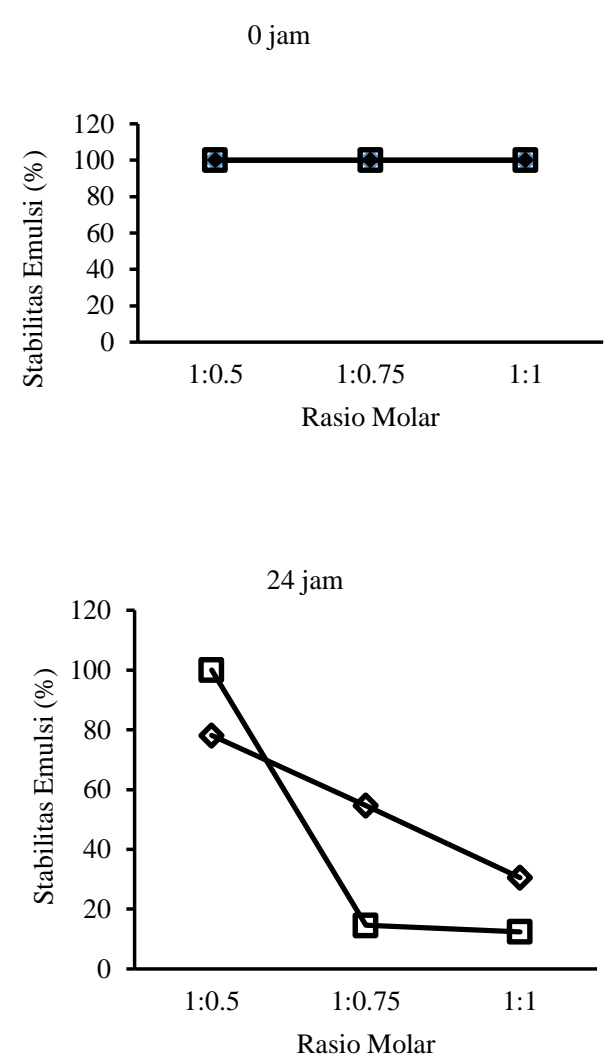
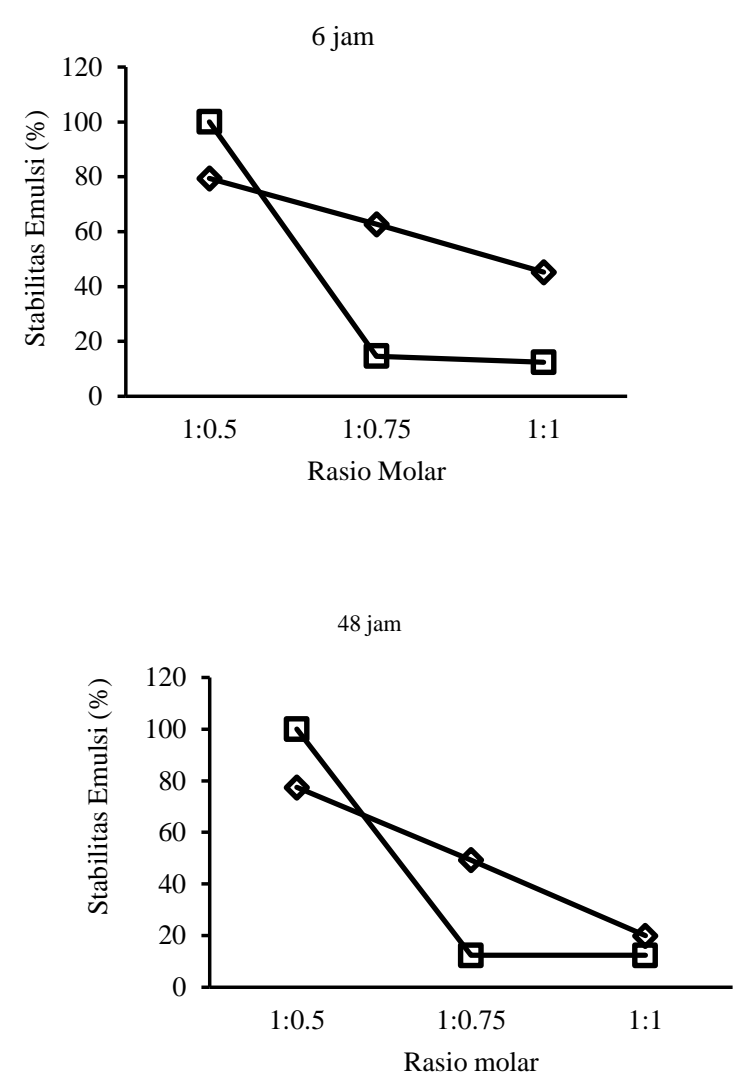

Gambar 8. Pengaruh jenis alkali dan rasio molar (asam laurat : NaOH-KOH) terhadap stabilitas emulsi selama penyimpanan pada suhu ruang. $\square-\mathrm{KOH}, \diamond-\mathrm{NaOH}$ 


\section{KESIMPULAN DAN SARAN}

\section{KESIMPULAN}

Rasio molar asam laurat dan $\mathrm{KOH} 30 \%$ terbaik adalah 1:0,5. Sifat fisikokimia foaming agent yang dihasilkan adalah sebagai berikut : nilai $\mathrm{pH}$ 9,88, densitas $0,9959 \mathrm{~g} / \mathrm{mL}$, viskositas $1,85 \mathrm{cP}$, tegangan permukaan 3,14 dyne/cm, tegangan antarmuka 8,39 dyne/cm, sudut kontak $18,28^{\circ}$ di menit ke-10 (dari 73,99 di menit ke 0). Berdasarkan hasil stabilitas busa dan stabilitas emulsi, kinerja foaming agent Na-laurat memiliki kinerja lebih baik dari K-laurat.

\section{SARAN}

Saran yang disampaikan berdasarkan hasil penelitian ini adalah perlu dilakukan perbaikan proses sintesis menggunakan suhu diatas $65^{\circ} \mathrm{C}$ dengan kecepatan dan tipe pengadukan yang berbeda.

\section{UCAPAN TERIMAKASIH}

Terima kasih diucapkan kepada BPDPKS atas bantuan dana riset yang diberikan sehingga penelitian dapat terlaksana dengan baik dan pada SBRC LPPM IPB atas fasilitas laboratorium yang digunakan.

\section{DAFTAR PUSTAKA}

[SNI] Standar Nasional Indonesia. 2006. Cara Uji Minyak dan Lemak SNI 01-3555-1998. Jakarta (ID): Badan Standardisasi Nasional.
[Dijtenbun] Direktorat Jenderal Perkebunan. 2016. Produksi Kelapa Sawit di Indonesia 2015. Jakarta (ID): Ditjenbun.

Belitz HD dan Grosch W. 2004. Food Chemistry. $3^{\text {rd }}$ ed. New York : Springer Verlag Berlin Heidebers.

Holmberg K, Jonssson B, Kronberg B, Lindman B. 2002. Surfactants and Polymers in Aqueous Solution. London (UK): John Wiley \& Sons, Ltd.

Kozeta V, Mevlude D, dan Marku J. 2011. Production of the anionic surfactant from soapstock of the sunflower oil. Natura Montenegrina. 9 (3): 773-783.

Król B, Prochaska K, dan Chrzanowski Ł. 2012. Biodegradability of firefighting foams. Journal Fire Technology. 48 (2): 173-181.

Piyali G, Bhirud RG, dan Kumar VV. 1999. Detergency and foam studies on linear alkylbenzene sulfonate and secondary alkyl sulfonate. Journal of Surfactant and Detergen. 2 (4) : 489 - 493.

Rondinini S, Buck RP, dan Covington AK. 2001. The measurement of $\mathrm{pH}$-definition, standards and procedures. Journal Pure Applied Chemistry. 74 (11):2169-2200.

Simeh MA. 2004. Comparative advantage of the european rapeseed industry vs other oils and fats producers. Oil Palm Industry Economic Journal. 4 (2): 14-22.

Suryani A, Sailah I, dan Hambali E. 2002. Teknologi Emulsi. Bogor (ID): IPB. 